\title{
Excavating the African American Experience in Iowa: A Review Essay
}

\section{BRUCE FEHN AND ROBERT F. JEFFERSON}

Outside In: African-American History in Iowa, 1838-2000, edited by Bill Silag, Susan Koch-Bridgford, and Hal Chase. Des Moines: State Historical Society of Iowa, 2001. xx, $580 \mathrm{pp}$. Illustrations, notes, index. $\$ 50.00$ cloth.

OUTSIDE IN is an informative, inspiring, at times exciting, and in some ways pathbreaking book. A collaborative, richly illustrated history, it provides a montage of black Iowans' struggles to claim their rights as American citizens, forge economic opportunities, and create their own family and community resources in the fight for self-preservation and dignity. It is filled with stories, many inviting further development, of black Iowans' experiences with white supremacy, discrimination, and segregation. As a pioneering venture into African American history in an overwhelmingly white state, the book implicitly and in some chapters explicitly calls on other lowans to recover additional stories of black Iowans and on historians to further interpret the meaning and significance of Iowa's black experience. The volume provides inspiration for much further work on African Americans and the history of race relations in the state. We hope that Iowa's citizens and historians will take up the call. Toward that end, we offer below a review of Outside In's main components and a discussion of some topics that scholars might consider as future avenues of inquiry and interpretation.

The authors wish to thank John Schacht for helpful comments and criticism.

THE ANNALS OF IOWA 61 (Fall 2002). (C) The State Historical Society of Iowa, 2002. 
THE BOOK is divided into five sections- "Two Perspectives on the Black Experience in Iowa," "The Rights and Responsibilities of Citizenship," "Economic Opportunity and Achievement," "Strengthening Iowa's Black Communities," and "Black Iowans in Sports, Entertainment, and the Arts" - with a total of twenty chapters, most of which hurry through broad spans of time to encapsulate the experiences of various groups and individuals. Within chapters of roughly twenty pages apiece, the contributors attempt to capture the evolution of the black experience in business, education, civil rights movements, the arts, athletics, and professional realms (such as law and medicine). Although offering few interpretive insights, the contributors narrate and document significant stories of black Iowans who found creative ways to attain access to education, economic opportunities, and political clout. Virtually every chapter emphasizes African American agency, showing how African Americans took individual action or mobilized collectively to defeat discrimination and challenge racism. Although the contributors fail to interpret the evolution of white supremacy in Iowa, along with its staggering economic and psychological costs, they have recovered fascinating stories of individuals whose courageous acts or dogged everyday actions eroded white domination and privilege.

In most chapters, contributors connect the African American presence in Iowa history to national historical issues. Accordingly, the social, political, economic, educational, and spatial configurations of African American life and culture in the state unfold against a canvas of slavery, Jim Crow segregation, World Wars I and II, black freedom struggles of the 1950s and 1960s, and fin de siècle American society. Meanwhile, contributors describe strategies that black Iowans devised to carve out their own unique spaces of community, family, and cultural production. The excitement generated from one selection to the next reminds one of a long-awaited motion picture film that not only lives up to its promise as it is viewed but provokes thought and discussion afterwards. Many selections are compelling in themselves, while suggesting new avenues of historical inquiry for anyone interested in the African American experience in Iowaas well as in other states in close proximity to the upper Mississippi and Missouri Rivers. 
Among the strongest chapters are those by Frances E. Hawthorne, Ralph Scharnau, Hal Chase, Alfredo Parrish, and Kathryn Neal, who emphasize the multifaceted dimensions of the black struggle for equality in the state's history. They reveal how individual action and pockets of organized resistance among workers, lawyers, educators, and physicians accrued across 162 years to form a social movement notable for its sheer, dogged protractedness. Hawthorne's chapter on African American churches provides a factual underpinning for the rise of black congregations and shows how places of worship became sites for civil rights mobilization and community improvement. In his fine chapter on Iowa workers, Ralph Scharnau explains how members of Iowa's industrial workforce forged interracial unions to obtain higher wages and equal opportunity for African Americans along with white workers. In an inspiring chapter on African Americans' presence in education, $\mathrm{Hal}$ Chase documents how teachers, parents, and students slowly prevailed over segregation, tokenism, and white supremacy to integrate educational facilities at all levels. Chase's contribution is especially strong because he intersperses his analysis with specific consideration of white supremacist attitudes prevalent in Iowa's educational history. Alfredo Parrish shows how Iowa's African American attorneys helped Iowans who risked their livelihoods in the "never-ending struggle to protect the rights of all American citizens" (282). And Kathryn M. Neal's chapter on African American women in Iowa chronicles the ways women functioned as kin and kith keepers in their respective communities. Like their counterparts in other regions of the United States, Iowa's African American women understood, as historian Deborah Gray White has shown elsewhere, that "if they worked for the poor, they worked for black women, and if they worked for black women they worked for the race. ${ }^{\prime \prime}$

BY UNEARTHING STORIES replete with insights into ways African Americans confronted racism, from overt acts of protest to dissembling, appropriation, and inversion of racist stereotypes,

1. Deborah Gray White, Too Heavy a Load: Black Women in Defense of Themselves, 1894-1994 (New York, 1999), 24. 
Outside In provides many evidentiary leads for stories that call for article-length treatment and fresh interpretation. For example, Richard, Lord Acton and Patricia Nassif Acton, in their excellent legal history, recover many examples of how African Americans used court cases to advance civil rights; most call out for additional research. Particularly compelling is the story of Edna Griffin, who in 1948 led a fight to integrate Katz Drug Store in Des Moines. Griffin, 39 years old at the time, was in the vanguard of new strategies to undermine racist power structures. Like other African Americans, Griffin had reevaluated approaches to racial justice pursued during the Great Depression and World War II. By the late 1940s, she and other African Americans were exploring new tactical approaches associated with direct action, such as the sit-ins, mass protests, and boycotts that became the hallmark of the civil rights movement of the 1950s and '60s.

Griffin also fought against police intimidation and harassment, one vitally important area of the black experience that unfortunately escaped the attention of contributors to Outside In. In 1951 and 1952, Griffin worked with another African American woman, Vina Simmons, to expose and demand prosecution for an alleged incident of police violence against African American Terry Lee Sims in a Sioux City jail. Simmons, a Sioux City community activist, filed a lawsuit accusing a Sioux City police officer of leading other police officers in an assault on Sims. Shortly before the Sims affair, Simmons had forced a Woodbury County grand jury investigation of the July 2, 1951, death of William Jackson in a Sioux City jail cell. Jackson died under suspicious circumstances, which included the temporary disappearance of his corpse. For her trouble, police harassed and intimidated Simmons, arresting her on trumped up charges of prostitution. Simmons fought back by suing the city for false arrest. Edna Griffin traveled to Sioux City to support Simmons in her battle against the police charges leveled against her. ${ }^{2}$

2. Kenneth L. Moon to Mrs. Stanley [Edna] Griffin, 22 September 1951; Edna M. Griffin to Russell Lasley, 29 September 1951; Russell Lasley to Russell Bull, "Confidential Report," "Sioux City Story," 26 March 1952; Zeke Geofreddi, Field Representative Report, 29 December 1951; Vina Simmons to Russell Lasley, 18 February 1952; Russell Lasley to Vina Simmons, 17 March 1952, all in folder 16, box 348, United Packinghouse Workers of America Records, State Historical Society of Wisconsin, Madison, Wisconsin. 
Even a cursory examination of this incident-and otherssuggests that researchers who take up the call to dig into black Iowans' past will discern cleavages among the working poor and middle-class blacks in Sioux City and elsewhere. They will learn also that African American and white women sometimes transcended race and class separations to coalesce around shared understandings based on gender.

By pursuing other local cases, researchers will find that black men sought to elevate their sense of manhood, which fueled participation in various political formations, such as the Black Panther Party (BPP) in Des Moines. Although Outside In largely ignores the BPP, and black nationalism in general, individual chapters provide clues for further research, development, and interpretation. For example, William S. Doan, in his chapter titled "Iowa and the Artist of African Descent," supplies eyecatching color reproductions of the works of black Iowa artists, including those by Jerry "Flakes" Burrell. Burrell's art explores black nationalist themes coursing through Des Moines in the late 1960s and early 1970s. Future historians can build upon Doan's work by investigating black cultural expression in Des Moines, the Black Panther Party and its community activities, as well as the party's confrontations with the police. In fact, no contributor mentions African Americans' often problematic relations with the police in Iowa's cities. ${ }^{3}$

In recent years, historians such as Robin D. G. Kelley, Tera Hunter, Earl Lewis, and Darlene Clark Hine have taught us that African Americans used not only overt or confrontational strategies to deal with racism; they developed complex and at times seemingly contradictory strategies that simultaneously eroded and reinforced white supremacy. ${ }^{4}$ David McMahon, in his chap-

3. Neither police nor law enforcement appear in the index. One would be equally hard pressed to find references to several other significant themes in Iowa's African American history, such as Acquired Immune Deficiency Syndrome, environmental concerns, poverty, and hip hop.

4. The literature relating to resistance is voluminous. For examples, see W. E. B. Du Bois, Black Reconstruction in America: An Essay Toward a History of the Part which Black Folk Played in the Attempt to Reconstruct Democracy in America, 1860 1880 (New York, 1935); James C. Scott, Weapons of the Weak: Everyday Forms of Peasant Resistance (New Haven, CT, 1985); James C. Scott, Domination and the Arts of Resistance: Hidden Transcripts (New Haven, CT, 1992); Earl Lewis, In 
ter on African Americans in sports, suggests that, in order to survive, black athletes inverted white stereotypes for their own purposes and sold them back to their oppressors. By taking club names such as the "Boone Brownies" and "Iowa Colored Boys," black teams satisfied the racist dispositions of their white audiences, while garnering for the players entry into much valued and relatively pleasant paid employment. In a 1920 advertisement in the Bystander, Iowa's foremost black newspaper, the Capital City Giants, an all-black baseball team from Des Moines, billed itself as a "Clean Exhibition" (470), which helped the team gain an audience in the virtually all-white communities throughout Iowa. At the same time, however, both the Giants and the Bystander reinforced the racist logic of white cleanliness and black filthiness.

Outside In sets the stage for more refined inquiries into the multifaceted nature of white supremacy in Iowa and the complicated strategies African Americans devised to handle it. Historians should ask questions such as: What toll did white racism, dissembling, and accommodation exact on individuals? What were the emotional and political costs? To what degree did much broader historical events such as the African Diaspora and anti-colonial struggles influence the thinking and lives of Iowa's African American citizens? ${ }^{5}$

EVERYONE responsible for Outside In should be commended for a pathbreaking volume from which anyone contemplating the history of minorities in other states can derive inspiration and guidance. We hope the volume appears in public and

Their Own Interests: Race, Class, and Power in Twentieth Century Norfolk, Virginia (Berkeley, CA, 1991); Robin D. G. Kelley, Hammer and Hoe: Alabama Communists During the Great Depression (Chapel Hill, NC, 1990); Robin D. G. Kelley, Race Rebels: Culture, Politics, and the Black Working Class (New York, 1994); Tera Hunter, To 'Joy My Freedom: Southern Black Women's Lives and Labors After the Civil War (Cambridge, MA, 1997); Darlene Clark Hine, "Rape and the Inner Lives of Black Women in the Middle West: Preliminary Thoughts on the Culture of Dissemblance," Signs 14 (1989), 912-20.

5. For more on dissemblance and the "logic" of white supremacist thinking, see Hine, "Rape and the Inner Lives of Black Women"; and Kevin K. Gaines, Uplifting the Race: Black Leadership, Politics, and Culture in the Twentieth Century (Chapel Hill, NC, 1996), 5. 
school libraries throughout the state. Outside In will have performed an important service if teachers and students of all ages refine and elaborate stories of African Americans struggling to control their destinies, sometimes with white allies and sometimes outside mainstream institutions. Teachers can deploy the volume's sidebar quotations and photos to have elementary and secondary school students write histories using these primary sources as starting points. College students in colloquia and seminars can follow the evidentiary leads provided by Outside In to develop further Iowa's African American history in civil rights movements, the arts, urban development, and other areas of black struggle and accomplishment. At the same time, the volume will serve as a very useful point of departure for more refined bibliographies of archival sources relating to the African American experience in Iowa.

As an engaging body of scholarship, Outside In sets the course for deeper historical accounts of African American educational history, civil rights in Iowa, and other topics. We hope the book will encourage academic historians and students at all levels to dig into Iowa's black history and employ new interpretive frameworks such as gender, masculinity, and whiteness studies to deepen our understanding of the African American experience in Iowa and elsewhere. Recognizing the enormous task presently facing students of Iowa history, Tom Morain may have stated in his introduction to Outside. In what was on the minds of all contributors:

We Iowans seem to have been able to overcome every division except one-race. No matter how large the city or how small [the] village, we have never fully escaped the racial divide. On either side of [the] line, we have continued to see the world as "we" and "them." Even as we begin the twenty-first century, we struggle to put aside distorted and antiquated formulations that mandate social and legal distinctions based on skin color. The dark side of community is that our sense of belonging can become stronger by focusing on who is excluded rather than the common interests of those within the circle (xvii).

Morain's formulation is sound. A study rich in public history, Outside In will serve as the opening salvo in both correcting and complicating our understanding of the history of all Iowans. 
Copyright of Annals of Iowa is the property of State of Iowa, by \& through the State Historical Society of Iowa and its content may not be copied or emailed to multiple sites or posted to a listserv without the copyright holder's express written permission. However, users may print, download, or email articles for individual use. 